Article

\title{
From Words to Deeds: The Impact of Pro-Environmental Self-Identity on Green Energy Purchase Intention
}

\author{
Magdalena Grębosz-Krawczyk ${ }^{1} \mathbb{D}$, Agnieszka Zakrzewska-Bielawska ${ }^{2, *(\mathbb{D})}$ and Sylwia Flaszewska $^{2} \mathbb{D}$ \\ 1 Department of European Integration and International Marketing, Faculty of Management and Production \\ Engineering, Lodz University of Technology, 90-924 Lodz, Poland; magdalena.grebosz@p.lodz.pl \\ 2 Department of Management, Faculty of Management and Production Engineering, Lodz University \\ of Technology, 90-924 Lodz, Poland; sylwia.flaszewska@p.lodz.pl \\ * Correspondence: agnieszka.zakrzewska-bielawska@p.lodz.pl
}

check for updates

Citation: Grębosz-Krawczyk, M.; Zakrzewska-Bielawska, A.;

Flaszewska, S. From Words to Deeds: The Impact of Pro-Environmental Self-Identity on Green Energy Purchase Intention. Energies 2021, 14, 5732. https://doi.org/10.3390/ en14185732

Academic Editors: Bernard Ziębicki and Edyta Bielińska-Dusza

Received: 18 August 2021

Accepted: 8 September 2021

Published: 11 September 2021

Publisher's Note: MDPI stays neutral with regard to jurisdictional claims in published maps and institutional affiliations.

Copyright: (c) 2021 by the authors. Licensee MDPI, Basel, Switzerland. This article is an open access article distributed under the terms and conditions of the Creative Commons Attribution (CC BY) license (https:// creativecommons.org/licenses/by/ $4.0 /)$.
Abstract: This study examines the mechanism by which pro-environmental self-identity (PESI) affects green energy purchase intention (GEPI) through different dimensions of consumption values. The concept of pro-environmental self-identity is rarely discussed in the context of green energy purchase intention. Additionally, the amount of research concerning consumers' attitudes and behaviours towards photovoltaic panels is limited. We fill this cognitive gap by testing a relation between pro-environmental self-identity and green energy purchase intention. The data collection was carried out based on an indirect method of gathering information-using an online survey. Research was conducted among 250 Polish customers. The partial least squares structural equation modelling technique was applied. The research results show that the relations between PESI and GEPI is mediated totally by social and partially by emotional values. The mediating impact of functional values was not confirmed. The results of this study illustrate the importance of intangiblesocial and emotional-values and its impact on the consumer behaviour toward green energy. This study can help marketers more efficiently promote the installation of photovoltaic panels in European countries.

Keywords: pro-environmental self-identity; green energy purchase intention; photovoltaic panels; social value; emotional value

\section{Introduction}

The development of the modern world, which has been driven mainly by the desire to improve people's quality of life, has been accompanied by an important increase in energy demand. In the second half of the XXth century, the international community started thinking about the increase in global energy consumption and its long-term consequences such as pollution of the atmosphere, soil and water. Nowadays, the eyes of the whole world are turned toward climate change. On the one hand, we need to increase energy production, but at the same time, it is necessary to protect the natural environment. Most countries in the world allocate important resources to encourage the use of renewable energy sources to protect natural resources and reduce pollution.

In 2020, the renewable energy use in the world increased 3\% while the demand for all other fuels decreased. It was caused by an almost $7 \%$ growth in electricity generation from renewable sources. Consequently, the share of renewables in worldwide electricity generation increased to $29 \%$ in 2020 (in comparison with $27 \%$ in 2019) [1]. Thanks to policy support, the market of photovoltaic panels has developed in China, the United States, India, Brazil and Vietnam. In total, electricity generated from photovoltaic panels is estimated to grow by 145 TWh (18\%), and will achieve about 1000 TWh by 2021 [1].

Previous research concerning green energy has concentrated especially on consumers' environmental concerns, attitudes, awareness, knowledge or responsibility [2-19], as well as internal and external factors influencing customers' intentions to adopt green energy [20-24]. 
The area of research concerning factors influencing consumer decisions in case of photovoltaic panels is still evolving in the scientific literature. We consequently observe important progress in the practical and theoretical aspects of this research [7,18,25-32]. Nonetheless, the international literature lacks a defined picture of the issues of pro-environmental self-identity that consumers of green energy are experiencing. Such information would provide both theoretical and managerial implications. Pro-environmental self-identity (PESI) has not been considered alongside consumption values and green energy purchase intention (GEPI) in the research regarding photovoltaic panel adoption. Consequently, we identified a research gap and confirmed the novelty of the problem. Previous papers concerning green energy adoption in Poland concentrated on the factors determining adoption by testing the willingness of customers to pay for green energy, to convert to green energy tariffs, and to install small-scale generators [29,33]. Therefore, the interconnection between the issue of pro-environmental self-identity and consumers' green energy purchase intention seems to be an innovation that this study brings compared with others that approached the same topic of study [7,18,25-32].

The objective of this paper is to evaluate the impact of pro-environmental self-identity on consumers' green energy purchase intention through different dimensions of chosen consumption values. The scientific problem was expressed through the following research question: How do functional, social and emotional values affect the relations between pro-environmental self-identity and consumers' green energy purchase intention?

This article can contribute to a better understanding of the importance of various factors influencing green energy purchase intention. The topic is important, taking into account the increasing use of photovoltaic panels and growing ecological attitudes of modern consumers. In their studies, Van Der Werff et al. [34], Barbarossa and de Pelsmacker [35] and Mutum et al. [36] highlighted the impact of self-identity on purchase intention of green products, but these issues were not discussed in the context of green energy adoption. Our contribution lies in using pro-environmental self-identity to explain sustainable energy adoption. We would like to strengthen this contribution by appraising the mediating effect of chosen consumption values between pro-environmental self-identity and green energy purchase intention.

The paper consists of five sections. The first is an introduction. The theoretical framework with characteristics of the European photovoltaic sector, the literature review concerning pro-environmental self-identity and its relation with consumption values and green energy purchase intention, and the hypotheses of the study are presented in Section 2. In Section 3, the research methodology is described. The results are presented in Section 4. To finish, in Section 5, the discussion and conclusions with managerial and theoretical contributions, as well as the limitations of this study, are formulated.

\section{Theoretical Framework}

\subsection{The Characteristics of the European Photovoltaic Sector}

In the past ten years, the EU has continued a proactive climate policy and incorporated a considerable amount of renewables into the energy system [37]. Therefore, renewable energy is one of the important areas of EU policy [38]. Renewable energy is a source of economic growth and jobs for Europeans. The larger amounts of renewable energy are a significant factor behind the decline in wholesale energy prices in previous years. It can in turn decrease energy costs for industry and possibly improve industrial competitiveness. Finally, the dropping costs of the technology, combined with digitalisation, is making renewables an important driving force for permitting consumers to play a central role in the energy transition [39].

EU countries, every second year, inform on their progress towards the EU's 2020 renewable energy goals. Based on the national statements, the European Commission creates an EU-wide report that gives an overview of renewable energy policy developments in EU countries. Available data show that the EU is on the right track for reaching its renewable energy goals for 2020. In 2018, twelve Member States already achieved a 
renewable energy share above their respective 2020 targets. Eleven other Member States met or exceeded their RED I average indicative trajectory for 2017-2018. Five Member States (France, Ireland, the Netherlands, Poland and Slovenia) failed to do so [39]. Ambitions of renewable energy targets are consistently raised in many countries [40].

One of the fastest growing renewable sources of electricity is solar energy. One of the most promising technologies all over the world is solar photovoltaic panels [41]. In 2020, 134 TWh of solar energy was produced in the EU-28 countries, mostly in Germany (49 TWh), Spain (15 TWh) and France (13 TWh). Poland's result was at the level of 1.9 TWh. This accounts for around $1.5 \%$ of the total electricity produced in Poland in 2020, which is seven times more than in 2018. This is mainly the result of the popularization of photovoltaic panels installed by prosumers and government forms of support, such as My Electricity program implemented from September 2019 to December 2020. It is estimated that in 2021 Poland will obtain as much as 3.5\% of its electricity from solar energy [42,43].

Referring to the increase in installed power in photovoltaics, it was about $153 \mathrm{GW}$ in the European Union countries. Germany did best with an increase of $4.74 \mathrm{GW}$, followed by the Netherlands $(3 \mathrm{GW})$ and Spain $(2.8 \mathrm{GW})$. Poland, with a result of $2.4 \mathrm{GW}$, was placed fourth. Detailed data on Poland prove that 2020 was the best year in the history of photovoltaic development. The installed power in photovoltaics was $3.936 \mathrm{MW}$ at the end of 2020, which means growth of $2.463 \mathrm{MW}$ year on year, translating to a $200 \%$ annual rise. Individual prosumers made the largest input to the increase in new power [43]. Importantly, despite the difficult period caused by the global pandemic, domestic photovoltaic made a significant contribution to the maintenance of investment processes to the tune of PLN 9.5 billion and provided Poland with 35 thousand jobs [43]. The growing ecological awareness of Polish people and the financial benefits associated with investing in a home photovoltaic installation translate into a large increase in interest in such a solution. Photovoltaic panels have proven themselves both as a technology that allows for a significant reduction in electricity bills and as an environmentally friendly solution [42,43].

The dynamics of the development of the photovoltaic market remains high in the EU-28 countries. Poland is the leader of Europe under the growth rate of photovoltaic power, calculated based on the compound annual growth rate (CAGR). Sweden, Hungary, Ukraine, the Netherlands and Spain are behind Poland [43].

\subsection{Consumers' Pro-Environmental Self-Identity (PESI) and Its Relation with Consumption Values and Green Energy Purchase Intention}

Pro-environmental self-identity (PESI)—also called green self-identity-is described as the consumers' self-obligation to protect the environment through their everyday behaviour [34,44]. Self-identity is a main predictor of consumption choice-making [45]. Consequently, it is significant also in explaining pro-environmental behaviour. In the opinion of Sparks and Shepherd [46], self-identity influence is stronger than attitudes and values. According to Dermody et al. [47] pro-environmental self-identity is an "environmentally friendly self-concept that is symbolically expressive and shaped by mainstream socio-cultural forces". Accordingly, pro-environmental self-identity is situationally cued. In consequence, these cues direct consumers' ecological behaviours [47-51].

Consumers with PESI tend to consider green behaviour an obligation that has a significant influence on the purchase intention of environmentally friendly products [52,53]. According to Van De Werff et al. [34], pro-environmental self-identity is related to consumers' obligation-based intrinsic motivation to behave pro-environmentally, and consequently it affects pro-ecological actions.

By practising green behaviours, consumers can feel better and perceive that their activities affect positively on environmental protection [36]. Bei and Simpson [54] stated that respondents perceived purchasing recycled products as an act of ecological protection and Wüstenhagen and Bilharz [16] found that the motivation for buying green electricity at a premium is to feel better about themselves.

Dermody et al. [47] confirmed that PESI has a significant influence on Polish and Chinese consumers' buying and curtailment behaviours. Thorbjørnsen et al. [55], Whit- 
marsh and O'Neill [50] and Mutum et al. [36] found that green consumption behaviours are correlated with PESI.

According to the theory of reasoned action (TRA) model, developed by Ajzen and Fishbein [56] and the theory of planned behaviour model proposed by Ajzen [57], an individual's performance of a specific behaviour is determined by his/her behavioural intention to perform the behaviour. In the case of studies concerning environmentally friendly consumer behaviours, the purchase intention of green products is understood as a customer's intention to buy a product that is less dangerous for both the environment and society [58]. Oliver and Lee [59] defined the purchase intention of the green product as a customer's real purchase of an environmentally friendly product once the customer is conscious of its ecological features. In our research, green energy purchase intention (GEPI) is related to the consumer's actual purchase or the consumer's intention to buy an environmentally friendly installation of photovoltaic panels.

In this context, a question arises whether the relation between PESI and green energy purchase intention is determined by any other factors. Seeking the answer, we used the consumption values theory. This theory provides fundamental and comprehensive constructs representing different values including functional, social, emotional, epistemic, and conditional values that are independent $[60,61]$. The consumption values theory was analysed in the context of green consumer behaviours by several researchers [61,62]. From different consumption values, three were supposed to be crucial for mediating the relation between PSEI and green energy purchase intention, which are: functional, social, and emotional values.

Functional value can be described as the perceived utility through the possession of the main functional, physical, or utilitarian attributes [60,63-66]. The positive impact of product utilitarian and physical attributes on the intention to purchase green products has been confirmed in different studies [32-38,41]. Wang et al. [67] and Yao et al. [68] also underlined the role of price-quality relation in the product evaluation. Consumers often complain about the high prices of green products, and they perceive ecological products as expensive in comparison to conventional ones. Consequently, a high price may influence purchase decisions, especially when consumers are price sensitive [69]. Previous research has confirmed the relation between price and green purchase intention [69-72]. In the case of green energy, purchases can be driven by functional value that determines the installation choice $[9,10]$. On the other hand PESI can determine the functional value because consumers are able to accept the green offer if its features and functions bring a potential positive effect to the environment. According to Chen and Chang [73], a consumer's opinion concerning the benefit of a product is based on the consumers' green needs, desires or sustainable expectations. Additionally, the study of Confente et al. [44] showed that the perceived functional value of green product is driven by consumers' pro-environmental self-identity. Therefore, we came up with following hypothesis:

Hypothesis 1 (H1). Functional value mediates the relation between pro-environmental selfidentity and green energy purchase intention.

Social value can be described as the perceived utility by the connotation with positively or negatively stereotyped demographic, cultural, social, economic, and ethnic groups [60,74]. According to the social identity theory (SIT), social membership gives an individual a sense of belonging [75]. The needs of belonging and acceptance by the group influences the choices of a consumer. Consequently, an individual defines himself through the prism of his group membership; that is, his place in the societal system. In this regard, social identity predefines an individual's attributes as a member of that group; that is, self-perception and conduct.

The adoption of solar PVs can be affected by social-interaction effects because social norms can encourage consumers to invest in pro-environmental activities [14,32,76-79]. Caird et al. [8], Kaenzig and Wüstenhagen [9], Salazar et al. [80], Lee [81] and Klepacka [11] confirmed a positive relation between social values and consumers' purchase behaviour 
toward environmentally friendly products. PESI is related with the way an individual sees himself and how he wants to follow the behaviours and values of the groups to which he wants to belong or belongs $[36,47,50]$. The conclusions from previously mentioned research suggest that the value system of a consumer can affect the value of green products and the degree to which the consumer identifies himself as a member of the green community. Therefore, we proposed a second hypothesis:

Hypothesis 2 (H2). Social value mediates the relation between pro-environmental self-identity and green energy purchase intention.

Emotional value can be defined as perceived utility related with a new product satisfying the consumer's sentimental needs and delivering novelty through the creation or perpetuation of feelings or affective states $[60,63,64]$.

Yoo et al. [82], Lin and Huang [64], Rex and Baumann [83] and Hartmann et al. [84] found a positive relationship between consumers' purchasing decisions and emotional value. On the other hand, there is also a positive relationship between pro-environmental self-identity and emotional value, which was proved among others by Confente et al. [44] and Mutum et al. [36]. Consumers can accept photovoltaic panels if the fit between the consumers' personal values and PV's modern traits is also underlined. The emotional value of green products can be influenced by consumers' pro-environmental self-identity, particularly if the consumer can see a strong similarity between himself and the product. Therefore, we assumed another hypothesis:

Hypothesis 3 (H3). Emotional value mediates the relation between pro-environmental self-identity and green energy purchase intention.

\section{Materials and Methods}

\subsection{Sample}

To achieve the objective of this research and to verify the hypotheses, the survey was conducted in January 2021. The sampling frame consisted of 250 Polish consumers who were house owners or co-owners. We used a self-administered questionnaire and random selection [85]. These consumers were selected from a database prepared by Norstat, which has a lot of experience in market research and offers online panels of 650,000 consumers from eighteen European countries who are highly motivated, pre-profiled, and open to various digital research methods. For Poland, the active panel counts 41,752 consumers over 18 years old. The population of Poland in 2020 was about 38.6 million people [86] and Internet penetration was 78\% [87].

In the first stage, a pilot test was conducted with ten randomly selected house owners. During the process, respondents checked the content and relevance of each item to make sure every question is adequate and accurately understood. Based on the feedback from pre-testing, minor modifications were made to the questionnaire.

In the second stage, the sample of 1000 consumers was randomly selected from a Norstat database of 12,329 consumers who are owners and co-owners of houses. Of this sample, 250 consumers (25\%) responded to the questionnaire. Such a response rate is acceptable for this type of survey [88]. Of these respondents, $43.6 \%$ were female and $56.4 \%$ were male (Table 1). Almost half of the respondents were people with higher education aged between 35 and 54 years old with houses that are more than 30 years old, mainly in the countryside. However, the women were younger than the men, and the men were better educated. 
Table 1. Demographic description of respondents.

\begin{tabular}{|c|c|c|c|}
\hline Demographic Descriptors & $\begin{array}{l}\text { General }(\%) \\
250=100 \%\end{array}$ & $\begin{array}{l}\text { Female }(\%) \\
\quad N=109\end{array}$ & $\begin{array}{c}\text { Male (\%) } \\
\mathrm{N}=141\end{array}$ \\
\hline \multicolumn{4}{|l|}{ Age } \\
\hline$<18-24>$ & 8.4 & 5.6 & 2.8 \\
\hline$<25-34>$ & 19.2 & 10.0 & 9.2 \\
\hline$<35-44>$ & 23.6 & 14.8 & 8.8 \\
\hline$<45-54>$ & 24.0 & 7.6 & 16.4 \\
\hline$<55-64>$ & 14.8 & 3.6 & 11.2 \\
\hline $65+$ & 10.0 & 2.0 & 8.0 \\
\hline \multicolumn{4}{|l|}{ Education } \\
\hline primary & 11.6 & 4.0 & 7.6 \\
\hline secondary & 41.2 & 22.4 & 18.8 \\
\hline higher & 47.2 & 17.2 & 30.0 \\
\hline \multicolumn{4}{|l|}{ Place of residence } \\
\hline countryside & 45.6 & 20.8 & 24.8 \\
\hline $\begin{array}{l}\text { city with population less than } \\
50 \text { thousand inhabitants }\end{array}$ & 26.4 & 12.8 & 13.6 \\
\hline $\begin{array}{l}\text { city with population from } 50 \text { up to } \\
150 \text { thousand inhabitants }\end{array}$ & 10.8 & 4.8 & 6.0 \\
\hline $\begin{array}{l}\text { city with population from } 150 \text { up to } \\
500 \text { thousand inhabitants }\end{array}$ & 11.6 & 3.6 & 8.0 \\
\hline $\begin{array}{l}\text { city with population bigger than } \\
500 \text { thousand inhabitants }\end{array}$ & 5.6 & 1.6 & 4.0 \\
\hline \multicolumn{4}{|l|}{ Age of house } \\
\hline less than 5 years & 7.2 & 3.6 & 3.6 \\
\hline $5-10$ years & 9.6 & 3.6 & 6.0 \\
\hline $11-20$ years & 22.4 & 7.2 & 15.2 \\
\hline 20-30 years & 14.4 & 8.4 & 6.0 \\
\hline over 30 years & 46.4 & 20.8 & 25.6 \\
\hline
\end{tabular}

To reduce biases, the respondents were asked to fill in the questionnaire on different days and time slots [89]. We checked the response bias issue based on the procedure suggested by Armstrong and Overton [90]. We compared early and late respondents and key demographic variables, such as gender, age, education, and place of residence using $\mathrm{t}$-tests. All $\mathrm{t}$-statistics were insignificant, suggesting that response bias was unlikely to affect our findings [91].

\subsection{Measures, Validation and Reliability Analysis}

The questionnaire consisted of 22 items taken from the literature measuring basic constructs, such as pro-environmental self-identity, green energy purchase intention, functional, social, and emotional value, and the demographic characteristics of respondents (indicated in a Table 1), which played the role of control variables. This study used existing scales from the literature focusing on consumption value theory as well as green consumers attitudes and behaviours. We used multi-item Likert scales (from 1-strongly disagree to 5-strongly agree) that are used in the literature for the purposes of constructing operationalization and allowing questioning without systematic errors [92]. A list of the scales used with associated items is presented in Appendix A. 
Pro-environmental self-identity (PESI) was measured by means of four items adapted from Barbarossa and de Pelsmacker [35], Dermody et al. [48], and Whitmarsh and O'Neill [50] through which the respondents were asked to indicate their level of agreement or disagreement with presented statements concerning their attitudes and behaviours to protect the environment. An example of the items we used is "I am willing to commit myself to environmental protection" or "I am convinced that my personal responsibility for the problems of the environment is important".

Green energy purchase intention (GEPI) was also measured by four items adapted from Yoo and Donthu [93] and Chan [94]. These items, e.g., "I have installed/would install photovoltaic panels instead of using conventional energy sources due to worsening environmental conditions" or "I would install/have installed photovoltaic panels for ecological reasons", focus on the intention of the consumer to buy a product that is less dangerous for both the environment and society (in this case photovoltaic panels).

Consumption values, such as functional, social, and emotional value measures were served as mediators in the relation between PESI and GEPI.

Functional value $(F V)$. Six items were used to measure functional value adopted from Sangroya and Nayak [4], Zailani et al. [65], and Sweeney and Soutar [62]. Some items described functional value in terms of economic utility and rationalism, such as "The photovoltaic panels are reasonably priced", and some consider product quality and attributes, such as "The photovoltaic panels available on the market are of good quality".

Social value $(S V)$. This value is measured by five items proposed by Sweeney and Soutar [62], Zailani et al. [65], and Yoo et al. [82], who described it as the gain acquired from acceptability in different social groups [95]. As example item is "Photovoltaic panels installation improves the image of its owner" or "Photovoltaic panel installation gives its owner social approval".

Emotional value (EV). This study defined emotional value as the perceived utility acquired from a customer's feelings. It used research from Yoo et al. [82], Arvola et al. [96], and Khan and Mohsin [97] to measure emotional value with three items, such as "Installing photovoltaic panels as an alternative to conventional energy sources would make me feel like a better person".

We followed a procedure proposed by Gerbing and Anderson [98] and Hair et al. [99] to evaluate the unidimensionality, validity, and reliability of the constructs. Because all our items are adopted from literature, we used a confirmatory factor analysis (CFA) with maximum likelihood estimation [100] to assess the reliability and validity of the multi-item scales. Table 2 presents the results of CFA.

All factor loadings were higher than 0.7 and all $\mathrm{t}$-tests of the observed variables were significant at the 0.001 level with $t$-values greater than 2 . In addition, the average variance extracted (AVE) values were higher than 0.50 . Consequently, we confirmed the convergent validity of the scales [101].

Discriminant validity helps to check the extent to which the constructs are statistically different from each other [101], suggesting that the square root of AVE of any construct should be higher than the inter-construct correlation. Table 3 shows that the square root of the AVE of the constructs exceeded the correlations of the constructs. There is one exception relating to the correlation between SV and EV. In this case, the correlation is higher than the square root of the AVE, which means that these variables should be considered in separate models instead of in one. Except for this limitation, discriminant validity was established. 
Table 2. The confirmatory factor analysis results.

\begin{tabular}{|c|c|c|c|c|c|}
\hline \multirow{2}{*}{ Variable/Items } & \multirow{2}{*}{ Loading } & \multirow{2}{*}{$t$-Value } & \multirow{2}{*}{$\begin{array}{c}\text { Convergent Validity } \\
\text { AVE }\end{array}$} & \multicolumn{2}{|c|}{ Reliability } \\
\hline & & & & Cronbach's $\alpha$ & CR \\
\hline \multicolumn{6}{|c|}{ Pro-environmental self-identity (PESI) } \\
\hline PESI 1 & 0.774 & - & \multirow{4}{*}{0.557} & \multirow{4}{*}{0.834} & \multirow{4}{*}{0.838} \\
\hline PESI 2 & 0.745 & 9.35 & & & \\
\hline PESI 3 & 0.703 & 8.83 & & & \\
\hline PESI 4 & 0.762 & 10.22 & & & \\
\hline \multicolumn{6}{|c|}{ Green energy purchase intention (GEPI) } \\
\hline GEPI 1 & 0.828 & - & \multirow{4}{*}{0.506} & \multirow{4}{*}{0.797} & \multirow{4}{*}{0.800} \\
\hline GEPI 2 & 0.752 & 5.77 & & & \\
\hline GEPI 3 & 0.768 & 4.75 & & & \\
\hline GEPI 4 & 0.774 & 9.21 & & & \\
\hline \multicolumn{6}{|c|}{ Functional value (FV) } \\
\hline FV 1 & 0.912 & - & \multirow{6}{*}{0.535} & \multirow{6}{*}{0.865} & \multirow{6}{*}{0.870} \\
\hline FV 2 & 0.864 & 13.35 & & & \\
\hline FV 3 & 0.695 & 9.16 & & & \\
\hline FV 4 & 0.605 & 8.18 & & & \\
\hline FV 5 & 0.643 & 9.43 & & & \\
\hline FV 6 & 0.675 & 9.59 & & & \\
\hline \multicolumn{6}{|l|}{ Social Value (SV) } \\
\hline SV 1 & 0.787 & - & \multirow{5}{*}{0.563} & \multirow{5}{*}{0.865} & \multirow{5}{*}{0.866} \\
\hline SV 2 & 0.719 & 7.01 & & & \\
\hline SV 3 & 0.722 & 6.63 & & & \\
\hline SV 4 & 0.765 & 9.04 & & & \\
\hline SV 5 & 0.758 & 9.18 & & & \\
\hline \multicolumn{6}{|c|}{ Emotional value (EV) } \\
\hline EV 1 & 0.721 & - & \multirow{3}{*}{0.601} & \multirow{3}{*}{0.811} & \multirow{3}{*}{0.817} \\
\hline EV 2 & 0.864 & 9.98 & & & \\
\hline EV 3 & 0.732 & 7.74 & & & \\
\hline
\end{tabular}

Table 3. Descriptive statistics, discriminant validity and correlations between variables.

\begin{tabular}{cccccc}
\hline Variable & PESI & GEPI & FV & SV & EV \\
\hline PESI & 0.746 & & & & \\
GEPI & $0.689^{* * *}$ & 0.712 & & & \\
FV & $0.602^{* * *}$ & $0.553^{* * *}$ & 0.731 & & \\
SV & $0.721^{* * *}$ & $0.689^{* * *}$ & $0.668^{* * *}$ & 0.750 & \\
EV & $0.727^{* * *}$ & $0.690^{* * *}$ & $0.683^{* * *}$ & $0.824^{* * *}$ & 0.775 \\
\hline Mean & 4.09 & 3.81 & 3.54 & 3.61 & 3.81 \\
s.d. & 0.75 & 0.82 & 0.68 & 0.78 & 0.84 \\
\hline
\end{tabular}

Note. $\mathrm{N}=250$; s.d.-standard deviation; the diagonal values (in bold) present the square roots of AVE; correlation is statistically significant for $p<0.01\left({ }^{* * *}\right)$.

The reliability of scales was conducted by calculating composite reliability (CR) and Cronbach's $\alpha$. Cronbach's alpha values for all the scales exceeded 0.7 and passed the recommended threshold level [99]. Similarly, the CR of all the constructs were above the threshold value of 0.7 , suggesting internal consistency and reliability [101].

To verify the extent to which our data are likely to suffer from common method bias, we guaranteed the anonymity of respondents and confidentiality of the study, affirmed that there are no correct or incorrect responses, and that they should respond honestly [102]. We also took care with particular items to ensure that they were not ambiguous, vague, or unfamiliar, and we formulated the questionnaire as concisely as possible, pre-testing it in a pilot study. 
In addition, we performed Harman's single factor test and we followed the approach of Podsakoff et al. [103] for controlling for an unmeasured latent factor. Common method variance is possible if items load on multiple factors and one factor does not account for most of the covariance. Our analysis, i.e., an unrotated principal component factor analysis, principal axis analysis with varimax rotation, and principal component analysis with varimax rotation revealed the presence offive 5 distinct factors with an eigenvalue greater than 1.0, rather than a single factor. The cumulative variance was $72.4 \%$. The first factor explains less than half of the overall variance (20.3\%), implying that single-source bias is not a significant concern.

Summing up, the CFA supported our measurement model and showed that proenvironmental self-identity, green energy purchase intention, functional value, social value, and emotional value are five distinct constructs.

For our analysis, we employed two statistical packages, Statistica and Amos, which enabled us to enter data in numerical form and then carry out statistical analyses, facilitating and accelerating the process of developing research results. In addition, Amos was useful for the visualization of the structural equations.

\section{Results}

To test our hypotheses, first we verified that there was no basis to reject the GaussMarkov assumptions following a procedure proposed by Hair et al. [99], then we performed structural equation modelling (SEM) with maximum likelihood (ML) estimation and covariance matrix as data inputs. This method is frequently selected to test and develop a theory [104]. Due to the mentioned limitation of discriminant validity (the correlation between SV and EV is higher than the square root of the AVE), we were not able to build one SEM model. Therefore, for our analyses, we built three separate SEM models to test the mediating impact of FV, SV, and EV on the relationship between PESI (independent variable) and GEPI (dependent variable). Firstly, we checked a direct effect, i.e., we tested whether the pro-environmental self-identity (PESI) affected green energy purchase intention (GEPI). Next, we examined the mediation (indirect) effect between independent (PESI) and dependent (GEPI) variables using particular mediators, such as FV, SV, and EV. For each model, we checked the following statistics: goodness of fit index (GFI), comparative fit index (CFI), root mean square error of approximation (RMSEA), TuckerLewis index (TLI), and adjusted goodness of fit index (AGFI). The results are presented in Figure 1 and Table 4.

Table 4. Results of structural equation modelling.

\begin{tabular}{|c|c|c|c|c|c|c|c|c|}
\hline \multirow{2}{*}{\multicolumn{3}{|c|}{ Path Analysis }} & \multicolumn{2}{|c|}{ Unstandar. Coefficients } & \multirow{2}{*}{ Standar. Coefficients $\beta$} & \multirow{2}{*}{$t$ Value } & \multirow{2}{*}{$p$ Value } & \multirow{2}{*}{ Results } \\
\hline & & & $B$ & SE & & & & \\
\hline \multicolumn{9}{|c|}{ Model 1} \\
\hline PESI & $\rightarrow$ & GEPI & 1.152 & 0.121 & 0.911 & 9.553 & $0.000^{* * *}$ & \multirow{3}{*}{$\begin{array}{c}\mathrm{H} 1 \\
\text { is not confirmed }\end{array}$} \\
\hline PESI & $\rightarrow$ & FV & 0.646 & 0.069 & 0.657 & 9.349 & $0.000 * * *$ & \\
\hline FV & $\rightarrow$ & GEPI & 0.016 & 0.096 & 0.012 & 0.165 & 0.869 & \\
\hline \multicolumn{9}{|c|}{ Model 2} \\
\hline PESI & $\rightarrow$ & GEPI & 0.400 & 0.248 & 0.321 & 1.611 & 0.107 & \multirow{3}{*}{$\begin{array}{c}\mathrm{H} 2 \\
\text { is confirmed }\end{array}$} \\
\hline PESI & $\rightarrow$ & SV & 0.860 & 0.084 & 0.927 & 10.265 & $0.000^{* * *}$ & \\
\hline SV & $\rightarrow$ & GEPI & 0.868 & 0.273 & 0.644 & 3.179 & $0.001^{* * *}$ & \\
\hline \multicolumn{9}{|c|}{ Model 3} \\
\hline PESI & $\rightarrow$ & GEPI & 0.516 & 0.222 & 0.408 & 2.325 & $0.020 *$ & \multirow{3}{*}{$\begin{array}{l}\mathrm{H} 3 \\
\text { is confirmed }\end{array}$} \\
\hline PESI & $\rightarrow$ & EV & 0.864 & 0.078 & 0.903 & 11.014 & $0.000^{* * *}$ & \\
\hline EV & $\rightarrow$ & GEPI & 0.745 & 0.235 & 0.564 & 3.170 & $0.002^{* * *}$ & \\
\hline
\end{tabular}

Note. $\mathrm{N}=250$; significance level for $p<0.01\left(^{* * *}\right)$; significance level for $p<0.05\left(^{*}\right)$; SE—standard error; $B$ —unstandardized path coefficient. 
(a) Functional value as mediator between PESI and GEPI

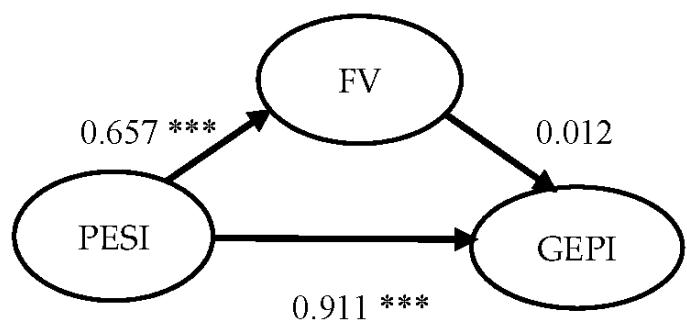

\begin{tabular}{crr}
\multicolumn{2}{c}{ Evaluation of the SEM model } \\
\hline $\begin{array}{c}\text { } \chi^{2 / d f} \\
\text { RMSEA }\end{array}$ & 0.091 & max. 2.00 \\
GFI & 0.946 & $<0.90 ; 1.00>$ \\
CFI & 0.976 & $<0.90 ; 1.00>$ \\
TLI & 0.948 & $<0.90 ; 1.00>$ \\
AGFI & 0.928 & $<0.90 ; 1.00>$ \\
\hline
\end{tabular}

(b) Social value as mediator between PESI and GEPI

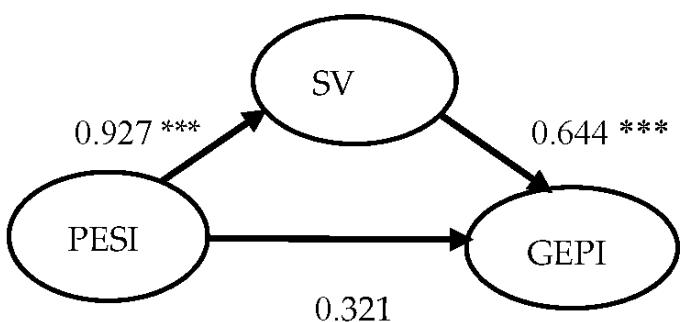

\begin{tabular}{ccc}
\hline \multicolumn{3}{c}{ Evaluation of the SEM model } \\
\hline $\begin{array}{c}\text { x } 2 / \text { df } \\
\text { RMSEA }\end{array}$ & 0.086 & $\max .2 .00$ \\
GFI & 0.908 & $<0.90 ; 1.00>$ \\
CFI & 0.963 & $<0.90 ; 1.00>$ \\
TLI & 0.928 & $<0.90 ; 1.00>$ \\
AGFI & 0.905 & $<0.90 ; 1.00>$ \\
\hline
\end{tabular}

(c) Emotional value as mediator between PESI and GEPI

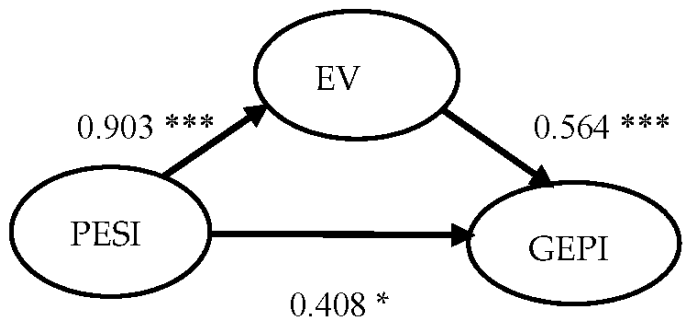

\begin{tabular}{ccc}
\hline \multicolumn{3}{c}{ Evaluation of the SEM model } \\
\hline $\begin{array}{c}c \\
\chi 2 / d f\end{array}$ & & max. 2.00 \\
RMSEA & 0.089 & max. 0.10 \\
GFI & 0.998 & $<0.90 ; 1.00>$ \\
CFI & 0.917 & $<0.90 ; 1.00>$ \\
TLI & 0.965 & $<0.90 ; 1.00>$ \\
AGFI & 0.937 & $<0.90 ; 1.00>$ \\
\hline
\end{tabular}

Figure 1. SEM models of direct and indirect (mediation) effect; Note. $\mathrm{N}=250$; significance level for $p<0.01\left(^{* * *}\right)$; significance level for $p<0.05\left(^{*}\right)$.

Hypothesis $\mathrm{H1}$, considering the mediation effect of the functional value (FV) on the relation between the pro-environmental self-identity (PESI) and green energy purchase intention (GEPI) must be rejected. There is no significant impact of FV on GEPI ( $\beta=0.012$; $p>0.05)$, therefore no mediation effect exists.

Social value (SV) is significantly associated with PESI $(\beta=0.927 ; p<0.01)$ and with GEPI ( $\beta=0.644 ; p<0.01)$, which supports Hypothesis H2. There is no significant impact of PESI on GEPI, which confirms total mediation effect. It means that the pro-environmental self-identity impacts consumers' green energy purchase intention but only through the social value, i.e., the perceived utility through the connotation with one or more social, economic, cultural, or demographic groups.

Emotional value (EV) partially mediates the relationship between PESI and GEPI. PESI is significantly associated with GEPI $(\beta=0.408 ; p<0.05)$ but also with EV ( $\beta=0.903$; $p<0.01)$, and EV is significantly associated with GEPI $(\beta=0.564 ; p<0.01)$. It means that PESI affects GEPI directly and indirectly through EV which expresses a partial mediation effect and confirms Hypothesis H3. 
Considering the control variables (respondents' gender, level of education, place of residence, and age of the house), some differences appeared. We grouped our respondents into two bigger subgroups (with minimum $n=60$ ) within a single control variable as follows: males $(n=141)$ and females $(n=109)$; younger people (18-44 years old; $n=128)$ and older people (over 44 years old; $n=122$ ); people with higher education $(n=118)$ and people with primary or secondary education $(n=132)$; people living in the countryside $(n=114)$ and people living in cities $(n=136)$; people who are owners of a house built less than 30 years ago $(n=134)$ and those who own a house built over 30 years ago $(n=116)$. The mediation effect of social value on the relation between pro-environmental self-identity and consumers' green energy purchase intention is:

- $\quad$ stronger for older people, i.e., people $45+$ years old ( $\beta=0.930 ; p<0.01$ for PESI $\rightarrow$ SV path dependence and $\beta=0.949 ; p<0.01$ for SV $\rightarrow$ GEPI path dependence),

- $\quad$ stronger for people with higher education $(\beta=0.936 ; p<0.01$ for PSEI $\rightarrow$ SV path dependence and $\beta=0.943 ; p<0.01$ for $\mathrm{SV} \rightarrow$ GEPI path dependence),

- $\quad$ weaker for people from cities ( $\beta=0.893 ; p<0.01$ for PESI $\rightarrow$ SV path dependence and $\beta=0.631 ; p<0.01$ for SV $\rightarrow$ GEPI path dependence), and

- $\quad$ weaker for owners who have had the house for a long time ( $\beta=0.867 ; p<0.01$ for PESI $\rightarrow$ SV path dependence and $\beta=0.505 ; p<0.01$ for SV $\rightarrow$ GEPI path dependence)

In the case of the mediation effect of emotional value on the relation between proenvironmental self-identity and consumers' purchase intention of photovoltaic panel installations, the following differences were identified:

- $\quad$ for people over 44 years old, the emotional value totally and strong mediates the relation between PESI and GEPI ( $\beta=0.928 ; p<0.01$ for PESI $\rightarrow$ EV path dependence and $\beta=0.607 ; p<0.01$ for EV $\rightarrow$ GEPI path dependence) as well as for owners who have had the house for over 30 years $(\beta=0.974 ; p<0.01$ for PESI $\rightarrow$ EV path dependence and $\beta=0.715 ; p<0.01$ for EV $\rightarrow$ GEPI path dependence),

- $\quad$ for people from cities, the emotional value totally but not as strongly mediates the relation between PSEI and GEPI ( $\beta=0.848 ; p<0.01$ for PESI $\rightarrow$ EV path dependence and $\beta=0 . ; p<0.01$ for EV $\rightarrow$ GEPI path dependence).

In both cases of mediation effects, i.e., impact of social and emotional values on the relation between PESI and GEPI, there were no statistically significant differences in terms of gender.

\section{Discussion and Conclusions}

The research results affirm the results of previous studies by Van Der Werff et al. [34], Barbarossa and de Pelsmacker [35] and Mutum et al. [36], who highlighted self-identity as an antecedent of purchase intention for green products. Our study focuses on consumers' intentional decision-making regarding photovoltaic panels in the context of proenvironmental self-identity and theory of consumption values, thus developing the discussion on crucial factors influencing green energy purchase intention, which contributes to sustainable development and it thus desirable in today's world.

Research results showed that the relationship between pro-environmental self-identity (PESI) and green energy purchase intention (GEPI) is mediated by social, and partially emotional, values. Other studies also confirmed that PESI mediates the relationship between values and consumer behaviour [34,50]. As Confente et al. [44] mentioned, pro-environmental self-identity is an important component of an individual's value-construction process.

The importance of social value was confirmed by Mutum et al. [36], who stated that social value mediated the relationship between PESI and green purchase behaviour (GPB). The research results also confirmed those of previous studies suggesting that social influence and environment respect affect consumers' green purchase behaviours [54,60,105]. PESI supports the positive associations of photovoltaic panels with eco-friendly communities and consequently in this context supports consumers' purchase behaviours. Consumers' personal self-obligation to protect the environment is reinforced by a need for social 
acceptance, which affects purchase intention. The relation between personal moral norms reinforced by public approval and intention of green purchase was also underlined by Chowdhury et al. [52] and Attaran and Celik [53]. External, expert opinions are important, especially for older people without experience with modern energy solutions who feel responsible for the environment.

Our research results also show that emotional value partially mediates the relation between pro-environmental self-identity and green energy purchase intention. This was consistent with the findings of Yoo et al. [82], Lin and Huang [64], Rex and Baumann [83] and Hartmann et al. [84] concerning a positive relationship between emotional value and purchasing decisions, as well as with the studies of Confente et al. [44] and Mutum et al. [36] regarding the mediating effect of values. The importance of the emotional value of green products is observed especially in the case of the most engaged consumers that expect to change something like in the case of older people having a house for a long time. Eco-friendly behaviours related to the installation of photovoltaic panels are driven by consumers' feelings of being green energy creators. The same was proved by Sparks and Shepherd [46] for consumers' intention to buy eco-friendly products, which were affected by individuals' perceptions of being eco, as well as by Mannetti et al. [106], who found that recycling behaviours are driven by consumers' feelings of being recyclers.

The research results did not find support for the mediation effect of functional value. Similar conclusions were formulated by Mutum et al. [36], who studied the relationship between PESI and green purchase behaviour (GPB). This was consistent also with the results of Ecker at al. [107] who stated that consumers chose green energy source especially for independence, autonomy, self-sufficiency, supply security, and control, and not functional value. However, the opposite conclusions were formulated by Confente et al. [44] for bioplastic products.

From a theoretical standpoint, the research results contribute to the pro-environmental self-identity concept and its relation with consumption value theory as well as providing a better understanding of consumers' purchase intentions towards photovoltaic panel installation and consequently the development possibilities in the green energy sector in Europe, a sector that is under-researched. This paper can be a starting point for a scientific discussion, but also can be used by managers working in the sector of green energy.

Considering managerial implications, this study's results can be useful for marketers, ecological organisations, policymakers, and public institutions in developing their policies, strategies, and marketing communication campaigns to encourage photovoltaic panel installation. The approach to understand consumers' green behaviours based on emotional and symbolic values has significant implications. Representatives of public institutions should understand that for citizens, social values are more important than functional benefits, and thus offer legal solutions that will allow the development of green local communities. Such communities can jointly support the development of green energy. The results of this study can have consequences for companies from the green energy sector. They can be used during the creation of marketing communication strategies, especially during the selection of communication tools and the formulation of advertising messages, taking into account the differences between groups of consumers. The most relevant social and emotional values should be communicated by different communication channels used by photovoltaic panel producers. The results prove that social value importantly mediates the relationship between PESI and GEPI. Consequently, marketers should present the opinions of experts and influencers to affect consumer behaviour by increasing trust in green energy and minimizing the perceived risks of photovoltaic panel installation. They can also refer to consumers' sense of social responsibility. Taking into account that emotional value was also found to partially mediate the relationship between PESI and GEPI, marketing communication campaigns of public institutions and ecological organisations should include emotional appeals to encourage consumers to adopt green energy and appealing to their sense of responsibility for the environment by showing the negative effects of the long-term use of conventional energy. 
These conclusions were formulated taking into account the sample's limitations. The study was limited to Polish consumers, the sample was relatively small, and we examined consumers' green energy purchase behaviour limited only to one source of green energy, i.e., photovoltaic panels. Therefore, this research can encourage further reflection on the impact of PESI and consumption values on green energy purchase intention. It seems interesting to undertake international studies enabling comparison between the attitudes of Polish consumers with consumers from other countries or expanding them to other sources of green energy and environmental knowledge as a mediator representing other consumer characteristics.

Author Contributions: General concept, M.G.-K. and A.Z.-B.; theory, M.G.-K. and S.F.; methodology, M.G.-K. and A.Z.-B.; validation and formal analysis, A.Z.-B.; investigation, M.G.-K.; data curation, A.Z.-B.; preparation of the draft version, M.G.-K., A.Z.-B. and S.F.; preparation of the draft version, M.G.-K., A.Z.-B. and S.F. All authors have read and agreed to the published version of the manuscript.

Funding: This research received no external funding.

Institutional Review Board Statement: Not applicable.

Informed Consent Statement: Not applicable.

Data Availability Statement: The data presented in this study are available on request from the corresponding author.

Conflicts of Interest: The authors declare no conflict of interest.

\section{Appendix A. Key Constructs and Items}

Pro-Environmental Self-Identity (PESI) [35,48,50]:

- $\quad$ (PESI 1) By buying photovoltaic panels, I help reduce environmental pollution.

- $\quad$ (PESI 2) I am willing to commit myself to environmental protection.

- (PESI 3) I am convinced that my personal responsibility for the problems of the environment is important.

- $\quad$ (PESI 4) I am convinced that my moral obligation to help the environment is important. Green Energy Purchase Intention (GEPI) [94,95]:

- $\quad$ (GEPI 1) I installed/would install photovoltaic panels instead of using conventional energy sources due to worsening environmental conditions.

- $\quad$ (GEPI 2) I installed/would install photovoltaic panels instead of using conventional energy sources when there are discounts or other promotional activities.

- $\quad$ (GEPI 3) I installed/would install photovoltaic panels instead of using conventional energy sources when there are external subsidies available.

- $\quad$ (GEPI 4) I would install/installed photovoltaic panels for ecological reasons.

\section{Functional Value (FV) $[4,63,66]$ :}

- $\quad$ (FV 1) The photovoltaic panels available on the market are of good quality.

- $\quad$ (FV 2) The photovoltaic panels available on the market are well made.

- $\quad$ (FV 3) Photovoltaic panels perform consistently.

- $\quad$ (FV 4) Photovoltaic panels are reasonably priced.

- $\quad$ (FV 5) Using photovoltaic panels offers value for money.

- $\quad$ (FV 6) Using photovoltaic panels offers future savings. Social Value (SV) [63,66,83]:

- $\quad$ (SV 1) Photovoltaic panel installation improves the image of its owner.

- $\quad$ (SV 2) Photovoltaic panel installation makes a good impression on other people.

- $\quad$ (SV 3) Photovoltaic panel installation gives its owner social approval.

- $\quad$ (SV 4) Photovoltaic panel installation reflects environmental awareness.

- $\quad$ (SV 5) Photovoltaic panel installation reflects concern for the environment.

Emotional Value (EV) $[83,97,98]$ : 
- $\quad$ (EV 1) Photovoltaic panel installation as an alternative to conventional energy sources seems to me to be a personal contribution to the common good.

- $\quad$ (EV 2) Photovoltaic panel installation as an alternative to conventional energy sources is morally right for me.

- $\quad$ (EV 3) Photovoltaic panel installation as an alternative of conventional energy sources would make me feel like a better person.

\section{References}

1. International Energy Agency (IEA) Global Energy Review 2021; International Energy Agency: Paris, France, 2021.

2. Bronfman, N.C.; Jiménez, R.B.; Arévalo, P.C.; Cifuentes, L.A. Understanding social acceptance of electricity generation sources. Energy Policy 2012, 46, 246-252. [CrossRef]

3. Hartmann, P.; Apaolaza-Ibáñez, V. Consumer attitude and purchase intention toward green energy brands: The roles of psychological benefits and environmental concern. J. Bus. Res. 2012, 65, 1254-1263. [CrossRef]

4. Sangroya, D.; Nayak, J.K. Factors influencing buying behaviour of green energy consumer. J. Clean. Prod. 2017, 151, 393-405. [CrossRef]

5. Niemeyer, S. Consumer voices: Adoption of residential energy-efficient practices. Int. J. Consum. Stud. 2010, 34, 140-145. [CrossRef]

6. Tsoutsos, T.; Drandaki, M.; Frantzeskaki, N.; Iosifidis, E.; Kiosses, I. Sustainable energy planning by using multi-criteria analysis application in the island of Crete. Energy Policy 2009, 37, 1587-1600. [CrossRef]

7. Sovacool, B.K.; Lakshmi Ratan, P. Conceptualizing the acceptance of wind and solar electricity. Renew. Sustain. Energy Rev. 2012, 16, 5268-5279. [CrossRef]

8. Caird, S.; Roy, R.; Herring, H. Improving the energy performance of UK households: Results from surveys of consumer adoption and use of low- and zero-carbon technologies. Energy Effic. 2008, 1, 149-166. [CrossRef]

9. Kaenzig, J.; Wüstenhagen, R. Understanding the green energy consumer. Mark. Rev. St. Gall. 2008, 25, 12-16. [CrossRef]

10. Sidiras, D.K.; Koukios, E.G. Solar systems diffusion in local markets. Energy Policy 2004, 32, 2007-2018. [CrossRef]

11. Klepacka, A.M. Significance of renewable energy sources in sustainable development. Ann. Pol. Assoc. Agric. Agribus. Econ. 2019, XXI, 55-64. [CrossRef]

12. Arkesteijn, K.; Oerlemans, L. The early adoption of green power by Dutch households. Energy Policy 2005, 33, 183-196. [CrossRef]

13. Litvine, D.; Wüstenhagen, R. Helping "light green" consumers walk the talk: Results of a behavioural intervention survey in the Swiss electricity market. Ecol. Econ. 2011, 70, 462-474. [CrossRef]

14. Ek, K.; Matti, S. Valuing the local impacts of a large scale wind power establishment in northern Sweden: Public and private preferences toward economic, environmental and sociocultural values. J. Environ. Plan. Manag. 2015, 58, 1327-1345. [CrossRef]

15. Gerpott, T.J.; Mahmudova, I. Determinants of price mark-up tolerance for green electricity-lessons for environmental marketing strategies from a study of residential electricity customers in Germany. Bus. Strateg. Environ. 2010, 19, 304-318. [CrossRef]

16. Wüstenhagen, R.; Bilharz, M. Green energy market development in Germany: Effective public policy and emerging customer demand. Energy Policy 2006, 34, 1681-1696. [CrossRef]

17. Kesari, B.; Atulkar, S.; Pandey, S. Consumer Purchasing Behaviour towards Eco-Environment Residential Photovoltaic Solar Lighting Systems. Glob. Bus. Rev. 2021, 22, 236-254. [CrossRef]

18. Pandey, S.; Kesari, B. Consumer purchase behaviour of solar equipments: Paradigm shift towards the ecological motivation among rural working consumers in developing countries. J. Adv. Res. Dyn. Control Syst. 2018, 10, 363-375.

19. Sigrin, B.; Pless, J.; Drury, E. Diffusion into new markets: Evolving customer segments in the solar photovoltaics market. Environ. Res. Lett. 2015, 10, 084001. [CrossRef]

20. Dubois, G.; Sovacool, B.; Aall, C.; Nilsson, M.; Barbier, C.; Herrmann, A.; Bruyère, S.; Andersson, C.; Skold, B.; Nadaud, F.; et al. It starts at home? Climate policies targeting household consumption and behavioral decisions are key to low-carbon futures. Energy Res. Soc. Sci. 2019, 52, 144-158. [CrossRef]

21. Ameli, N.; Brandt, N. Determinants of households' investment in energy efficiency and renewables: Evidence from the OECD survey on household environmental behaviour and attitudes. Environ. Res. Lett. 2015, 10, 044015. [CrossRef]

22. Michelsen, C.C.; Madlener, R. Homeowners' preferences for adopting innovative residential heating systems: A discrete choice analysis for Germany. Energy Econ. 2012, 34, 1271-1283. [CrossRef]

23. Niamir, L.; Ivanova, O.; Filatova, T.; Voinov, A.; Bressers, H. Demand-side solutions for climate mitigation: Bottom-up drivers of household energy behavior change in the Netherlands and Spain. Energy Res. Soc. Sci. 2020, 62, 101356. [CrossRef]

24. Mills, B.; Schleich, J. Residential energy-efficient technology adoption, energy conservation, knowledge, and attitudes: An analysis of European countries. Energy Policy 2012, 49, 616-628. [CrossRef]

25. Zhai, P.; Williams, E.D. Analyzing consumer acceptance of photovoltaics (PV) using fuzzy logic model. Renew. Energy 2012, 41, 350-357. [CrossRef]

26. Myojo, S.; Ohashi, H. Effects of consumer subsidies for renewable energy on industry growth and social welfare: The case of solar photovoltaic systems in Japan. J. Jpn. Int. Econ. 2018, 48, 55-67. [CrossRef] 
27. Wolske, K.S.; Todd, A.; Rossol, M.; McCall, J.; Sigrin, B. Accelerating demand for residential solar photovoltaics: Can simple framing strategies increase consumer interest? Glob. Environ. Chang. 2018, 53, 68-77. [CrossRef]

28. Schelly, C. Residential solar electricity adoption: What motivates, and what matters? A case study of early adopters. Energy Res. Soc. Sci. 2014, 2, 183-191. [CrossRef]

29. Klepacka, A.M.; Florkowski, W.J.; Meng, T. Clean, accessible, and cost-saving: Reasons for rural household investment in solar panels in Poland. Resour. Conserv. Recycl. 2018, 139, 338-350. [CrossRef]

30. Mundaca, L.; Samahita, M. What drives home solar PV uptake? Subsidies, peer effects and visibility in Sweden. Energy Res. Soc. Sci. 2020, 60, 101319. [CrossRef]

31. Colasante, A.; D'Adamo, I.; Morone, P. Nudging for the increased adoption of solar energy? Evidence from a survey in Italy. Energy Res. Soc. Sci. 2021, 74, 101978. [CrossRef]

32. Noll, D.; Dawes, C.; Rai, V. Solar Community Organizations and active peer effects in the adoption of residential PV. Energy Policy 2014, 67, 330-343. [CrossRef]

33. Kowalska-Pyzalska, A. An empirical analysis of green electricity adoption among residential consumers in Poland. Sustainability 2018, 10, 2281. [CrossRef]

34. Van der Werff, E.; Steg, L.; Keizer, K. It is a moral issue: The relationship between environmental self-identity, obligation-based intrinsic motivation and pro-environmental behaviour. Glob. Environ. Chang. 2013, 23, 1258-1265. [CrossRef]

35. Barbarossa, C.; De Pelsmacker, P. Positive and Negative Antecedents of Purchasing Eco-friendly Products: A Comparison Between Green and Non-green Consumers. J. Bus. Ethics 2016, 134, 229-247. [CrossRef]

36. Mutum, D.S.; Ghazali, E.M.; Wei-Pin, W. Parallel mediation effect of consumption values and the moderation effect of innovativeness, in predicting the influence of identity on green purchasing behavior. J. Consum. Behav. 2021, 20, 827-844. [CrossRef]

37. Tagliapietra, S.; Zachmann, G.; Edenhofer, O.; Glachant, J.M.; Linares, P.; Loeschel, A. The European union energy transition: Key priorities for the next five years. Energy Policy 2019, 132, 950-954. [CrossRef]

38. Hajdukiewicz, A.; Pera, B. zena International trade disputes over renewable energy-The case of the solar photovoltaic sector. Energies 2020, 13, 500. [CrossRef]

39. European Commission. Renewable Energy Progress Report; European Commission: Brussels, Belgium, 2020.

40. Gielen, D.; Boshell, F.; Saygin, D.; Bazilian, M.D.; Wagner, N.; Gorini, R. The role of renewable energy in the global energy transformation. Energy Strateg. Rev. 2019, 24, 38-50. [CrossRef]

41. Bianco, V.; Cascetta, F.; Nardini, S. Analysis of technology diffusion policies for renewable energy. The case of the Italian solar photovoltaic sector. Sustain. Energy Technol. Assess. 2021, 46, 101250. [CrossRef]

42. Grębosz-Krawczyk, M.; Zakrzewska-Bielawska, A.; Glinka, B.; Glińska-Neweś, A. Why do consumers choose photovoltaic panels? Identification of the factors influencing consumers' choice behavior regarding photovoltaic panel installations. Energies 2021, 14, 2674. [CrossRef]

43. Institute for Renewable Energy. PV Market in Poland; Institute for Renewable Energy: Warsaw, Poland, 2021.

44. Confente, I.; Scarpi, D.; Russo, I. Marketing a new generation of bio-plastics products for a circular economy: The role of green self-identity, self-congruity, and perceived value. J. Bus. Res. 2020, 112, 431-439. [CrossRef]

45. Belk, R.W. The ineluctable mysteries of possessions. J. Soc. Behav. Personal. 2010, 6, 17-55.

46. Sparks, P.; Shepherd, R. Self-Identity and the Theory of Planned Behavior: Assesing the Role of Identification with "Green Consumerism". Soc. Psychol. Q. 1992, 55, 388-399. [CrossRef]

47. Dermody, J.; Koenig-Lewis, N.; Zhao, A.L.; Hanmer-Lloyd, S. Appraising the influence of pro-environmental self-identity on sustainable consumption buying and curtailment in emerging markets: Evidence from China and Poland. J. Bus. Res. 2018, 86, 333-343. [CrossRef]

48. Dermody, J.; Hanmer-Lloyd, S.; Koenig-Lewis, N.; Zhao, A.L. Advancing sustainable consumption in the UK and China: The mediating effect of pro-environmental self-identity. J. Mark. Manag. 2015, 31, 1472-1502. [CrossRef]

49. Kashima, Y.; Paladino, A.; Margetts, E.A. Environmentalist identity and environmental striving. J. Environ. Psychol. 2014, 38, 64-75. [CrossRef]

50. Whitmarsh, L.; O'Neill, S. Green identity, green living? The role of pro-environmental self-identity in determining consistency across diverse pro-environmental behaviours. J. Environ. Psychol. 2010, 30, 305-314. [CrossRef]

51. Smith, E.R.; Semin, G.R. Situated social cognition. Curr. Dir. Psychol. Sci. 2007, 16, 132-135. [CrossRef]

52. Chowdhury, M.; Salam, K.; Tay, R. Consumer preferences and policy implications for the green car market. Mark. Intell. Plan. 2016, 34, 810-827. [CrossRef]

53. Attaran, S.; Celik, B.G. Students' environmental responsibility and their willingness to pay for green buildings. Int. J. Sustain. High. Educ. 2015, 16, 327-340. [CrossRef]

54. Bei, L.; Simpson, E. The determinants of consumers' purchase decisions for recycled products: An application of acquisition transaction utility theory. Adv. Consum. Res. 1995, 22, 257-262.

55. Thorbjørnsen, H.; Pedersen, P.E.; Nysveen, H. "This is who i am": Identity expressiveness and the theory of planned behavior. Psychol. Mark. 2007, 24, 763-785. [CrossRef]

56. Ajzen, I.; Fishbein, M. Understanding Attitudes and Predicting Social Behavior; Cliffs, E., Ed.; Prentice-Hall: New York, NY, USA, 1980.

57. Ajzen, I. The theory of planned behavior. Organ. Behav. Hum. Decis. Process. 1991, 50, 179-211. [CrossRef] 
58. Mohd Suki, N. Green product purchase intention: Impact of green brands, attitude, and knowledge. Br. Food J. 2016, 118, 2893-2910. [CrossRef]

59. Oliver, J.D.; Lee, S. Hybrid car purchase intentions: A cross-cultural analysis. J. Consum. Mark. 2010, 27, 96-103. [CrossRef]

60. Sheth, J.N.; Newman, B.I.; Gross, B.L. Why we buy what we buy: A theory of consumption values. J. Bus. Res. 1991, 22, 159-170. [CrossRef]

61. Lin, P.; Huang, Y.; Wang, J. Applying the theory of consumption values to choice behavior toward green products. In Proceedings of the 2010 IEEE International Conference on Management of Innovation \& Technology, Singapore, 2-5 June 2010; pp. $348-353$.

62. Sweeney, J.C.; Soutar, G.N. Consumer perceived value: The development of a multiple item scale. J. Retail. 2001, 77, 203-220. [CrossRef]

63. Mohd Suki, N.; Mohd Suki, N. Consumption values and consumer environmental concern regarding green products. Int. J. Sustain. Dev. World Ecol. 2015, 22, 269-278. [CrossRef]

64. Lin, P.-C.; Huang, Y.-H. The influence factors on choice behavior regarding green products based on the theory of consumption values. J. Clean. Prod. 2012, 22, 11-18. [CrossRef]

65. Zailani, S.; Iranmanesh, M.; Hyun, S.S.; Ali, M.H. Applying the theory of consumption values to explain drivers'willingness to pay for biofuels. Sustainability 2019, 11, 668. [CrossRef]

66. Jaderná, E.; Přikrylová, J. Green solutions in automotive industry. Mark. Sci. Inspir. 2018, 13, $2-11$.

67. Wang, H.; Ma, B.; Bai, R. How does green product knowledge effectively promote green purchase intention? Sustainability 2019, 11, 1193. [CrossRef]

68. Sang, P.; Yao, H.; Zhang, L.; Wang, S.; Wang, Y.; Liu, J. Influencing factors of consumers' willingness to purchase green housing: A survey from Shandong Province, China. Environ. Dev. Sustain. 2020, 22, 4267-4287. [CrossRef]

69. Yue, B.; Sheng, G.; She, S.; Xu, J. Impact of Consumer Environmental Responsibility on Green Consumption Behavior in China: The Role of Environmental Concern and Price Sensitivity. Sustainability 2020, 12, 2074. [CrossRef]

70. Gleim, M.R.; Smith, J.S.; Andrews, D.; Cronin, J.J. Against the green: A multi-method examination of the barriers to green consumption. J. Retail. 2013, 89, 44-61. [CrossRef]

71. Padel, S.; Foster, C. Exploring the gap between attitudes and behaviour. Br. Food J. 2005, 107, 606-625. [CrossRef]

72. Vermeir, I.; Verbeke, W. Sustainable food consumption among young adults in Belgium: Theory of planned behaviour and the role of confidence and values. Ecol. Econ. 2008, 64, 542-553. [CrossRef]

73. Chen, Y.S.; Chang, C.H. Enhance green purchase intentions: The roles of green perceived value, green perceived risk, and green trust. Manag. Decis. 2012, 50, 502-520. [CrossRef]

74. Yadav, R.; Pathak, G.S. Young consumers' intention towards buying green products in a developing nation: Extending the theory of planned behavior. J. Clean. Prod. 2016, 135, 732-739. [CrossRef]

75. Tajfel, H. Social identity and intergroup behaviour. Soc. Sci. Inf. 1974, 13, 65-93. [CrossRef]

76. Bollinger, B.; Gillingham, K. Peer Effects in the Diffusion of Solar Photovoltaic Panels. Mark. Sci. 2012, 31, 900-912. [CrossRef]

77. Graziano, M.; Gillingham, K. Spatial patterns of solar photovoltaic system adoption: The influence of neighbors and the built environment. J. Econ. Geogr. 2015, 15, 815-839. [CrossRef]

78. Jager, W. Stimulating the diffusion of photovoltaic systems: A behavioural perspective. Energy Policy 2006, 34, 1935-1943. [CrossRef]

79. Gadenne, D.; Sharma, B.; Kerr, D.; Smith, T. The influence of consumers' environmental beliefs and attitudes on energy saving behaviours. Energy Policy 2011, 39, 7684-7694. [CrossRef]

80. Salazar, H.A.; Oerlemans, L.; van Stroe-Biezen, S. Social influence on sustainable consumption: Evidence from a behavioural experiment. Int. J. Consum. Stud. 2013, 37, 172-180. [CrossRef]

81. Lee, K. The Green Purchase Behavior of Hong Kong Young Consumers: The Role of Peer Influence, Local Environmental Involvement, and Concrete Environmental Knowledge. J. Int. Consum. Mark. 2010, 23, 21-44. [CrossRef]

82. Yoo, J.-J.; Divita, L.; Kim, H.-Y. Environmental awareness on bamboo product purchase intentions: Do consumption values impact green consumption? Int. J. Fash. Des. Technol. Educ. 2013, 6, 27-34. [CrossRef]

83. Rex, E.; Baumann, H. Beyond ecolabels: What green marketing can learn from conventional marketing. J. Clean. Prod. 2007, 15, 567-576. [CrossRef]

84. Hartmann, P.; Apaolaza Ibáñez, V.; Forcada Sainz, F.J. Green branding effects on attitude: Functional versus emotional positioning strategies. Mark. Intell. Plan. 2005, 23, 9-29. [CrossRef]

85. Groves, R.M.; Fowler, F.J.; Couper, M.P.; Lepkowski, J.M.; Singer, E.; Tourangeau, R. Survey Methodology; Wiley: New York, NY, USA, 2011.

86. Poland Population. Available online: https:/ / countrymeters.info/en/Poland\#population_2020 (accessed on 16 December 2020).

87. Norstat Panelbook. Available online: www.norstatgroup.com (accessed on 6 January 2021).

88. Baruch, Y. Response Rate in Academic Studies-A Comparative Analysis. Hum. Relat. 1999, 52, 421-438. [CrossRef]

89. Sakshaug, J.W.; Yan, T.; Tourangeau, R. Nonresponse Error, Measurement Error, and Mode of Data Collection: Tradeoffs in a Multi-mode Survey of Sensitive and Non-sensitive Items. Public Opin. Q. 2010, 74, 907-933. [CrossRef]

90. Armstrong, J.S.; Overton, T.S. Estimating nonresponse bias in mail surveys. J. Mark. Res. 1977, 14, 396-402. [CrossRef]

91. Werner, S.; Praxedes, M.; Kim, H.-G. The reporting of nonresponse analyses in survey research. Organ. Res. Methods 2007, 10, 287-295. [CrossRef] 
92. Lee, M.K.O.; Turban, E. A trust model for consumer internet shopping. Int. J. Electron. Commer. 2001, 6, 75-91. [CrossRef]

93. Yoo, B.; Donthu, N. Developing and validating a multidimensional consumer-based brand equity scale. J. Bus. Res. 2001, 52, 1-14. [CrossRef]

94. Chan, R.Y.K. Determinants of Chinese consumers' green purchase behavior. Psychol. Mark. 2001, 18, 389-413. [CrossRef]

95. Jamrozy, U.; Lawonk, K. The multiple dimensions of consumption values in ecotourism. Int. J. Cult. Tour. Hosp. Res. 2017, 11, 18-34. [CrossRef]

96. Arvola, A.; Vassallo, M.; Dean, M.; Lampila, P.; Saba, A.; Lähteenmäki, L.; Shepherd, R. Predicting intentions to purchase organic food: The role of affective and moral attitudes in the Theory of Planned Behaviour. Appetite 2008, 50, 443-454. [CrossRef] [PubMed]

97. Khan, S.N.; Mohsin, M. The power of emotional value: Exploring the effects of values on green product consumer choice behavior. J. Clean. Prod. 2017, 150, 65-74. [CrossRef]

98. Gerbing, D.W.; Anderson, J.C. An updated paradigm for scale development incorporating unidimensionality and its assessment. J. Mark. Res. 1988, 25, 186-192. [CrossRef]

99. Hair, J.; Black, W.; Babin, B.; Anderson, R. Multivariate Data Analysis; Prentice-Hall: Upper Saddle River, NJ, USA, 2010.

100. Schumacker, R.E. A Beginner's Guide to Structural Equation Modeling; Routledge: London, UK, $2012 ;$ ISBN 9780203851319.

101. Fornell, C.; Larcker, D.F. Evaluating structural equation models with unobservable variables and measurement error. J. Mark. Res. 1981, 18, 39-50. [CrossRef]

102. Chang, S.J.; Van Witteloostuijn, A.; Eden, L. From the Editors: Common method variance in international business research. J. Int. Bus. Stud. 2010, 41, 178-184. [CrossRef]

103. Podsakoff, P.M.; MacKenzie, S.B.; Podsakoff, N.P. Sources of method bias in social science research and recommendations on how to control it. Annu. Rev. Psychol. 2012, 63, 539-569. [CrossRef] [PubMed]

104. Thakkar, J.J. Introduction to Structural Equation Modelling. In Studies in Systems, Decision and Control; Springer: Singapore, 2020; pp. 1-11.

105. Pickett-Baker, J.; Ozaki, R. Pro-environmental products: Marketing influence on consumer purchase decision. J. Consum. Mark. 2008, 25, 281-293. [CrossRef]

106. Mannetti, L.; Pierro, A.; Livi, S. Recycling: Planned and self-expressive behaviour. J. Environ. Psychol. 2004, 24, 227-236. [CrossRef]

107. Ecker, F.; Hahnel, U.J.J.; Spada, H. Promoting decentralized sustainable energy systems in different supply scenarios: The role of autarky aspiration. Front. Energy Res. 2017, 5, 14. [CrossRef] 